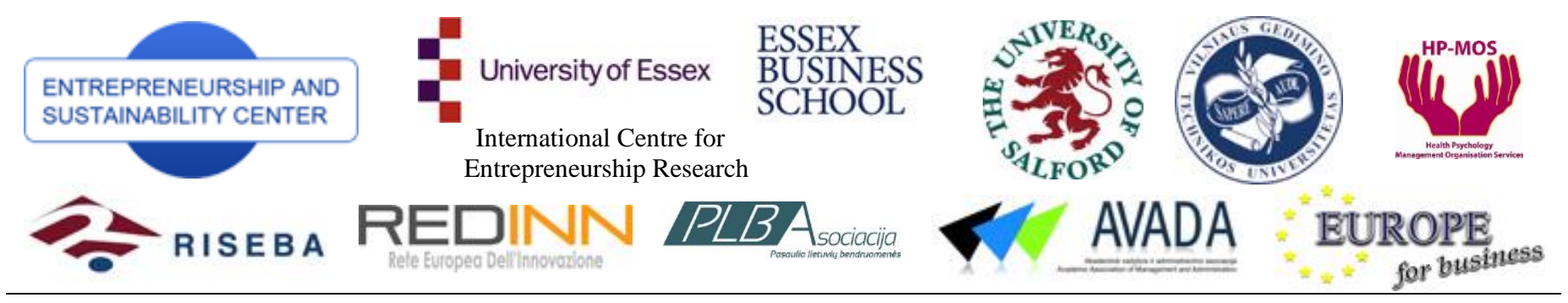

The International Journal ENTREPRENEURSHIP AND SUSTAINABILITY ISSUES

ISSN 2345-0282 (online) http://jssidoi.org/jesi/aims-and-scope-of-research/ 2015 Volume 2 Number 3 (March)

\title{
ENTREPRENEURSHIP ECOSYSTEM: METHODOLOGICAL APPROACHES TO FUNCTIONS' REVIEW OF PUBLIC SECTOR INSTITUTIONS
}

\author{
Živilè Tunčikiene் $\dot{1}^{1}$, Rolandas Drejeris ${ }^{2}$ \\ ${ }^{1,2}$ Department of Social Ecomonics and Management, Faculty of Business Management, Vilnius Gediminas Technical \\ University, Sauletekio str. 11, LT-10223, Vilnius, Lithuania \\ E-mails: ${ }^{\prime}$ zivile.tuncikiene@vgtu.lt (correspondingauthor); ${ }^{2}$ rolandas.drejeris@vgtu.lt
}

Received 10 November 2014; accepted 7 January 2015

\begin{abstract}
Progress of small and medium business is influenced by many environmental factors and conditions, perceived as entrepreneurship ecosystem. A major element of this ecosystem is public sector, more specifically, the services provided by public sector. In the context of growing environmental demands and expectations in respect of public sector, it becomes necessary to justify the activities of institutions in the light of creating the preconditions for implementing the priorities of country's development. For this purpose, application of the functions review method in public sector has been internationally recognised as appropriate. While public institutions carry out reviews of functions, they face with methodological level problems which aren't still resolved in essence. A major issue is the methodological approach to functions review. A methodological basis of such review provided in special literature is insufficient. Our research allowed to supplement the methodological basis of functions review with well-founded approaches and to systemise methodological provisions for functions review. This article contains both the original recommendations on how to assess factors which determine selection of the methodological approaches for functions review and the regularities of links between such factors and methodological approaches which are recommended in setting an integrated combination of the methodological approaches for particular situation of public institutions.
\end{abstract}

Keywords: entrepreneurship, institutions, activities, functions (al) review, strategic planning, methodological basis, sustainable development

Reference to this paper should be made as follows: Tunčikienè, Ž.; Drejeris, R. 2015. Entrepreneurship ecosystem: methodological approaches to functions' review of public sector institutions, Entrepreneurship and Sustainability Issues 2(3): 118-132.

DOI: http://dx.doi.org/10.9770/jesi.2014.2.3(1)

JEL Classifications: H83

\section{Introduction}

The role of public sector, as an element of entrepreneuship ecosystem, which creats increasingly better conditions for business development and facilitates sustainable development of any country, has been highlighted in a number of research articles (Bileišis 2014; Greblikaitè, Puškoriūtè 2014; Samoška 2011, 2013; Korsakienė, Tvaronavičienė 2014; Giriūnienė 2013; Šimelytė, Antanavičienè 2013; De Alencar, Almeida 2013; Išoraitė 2013; Wahl, Prause 2013; Tvaronavičienė 2014; Prause, Hunke 2014; Caurkubule, Rubanovskis 2014; Garškaitè-Milvydienė 2014; Šabasevičienè, Grybaitė 2014; Raudeliūnienė et al. 2014; Antanavičienė 2014; Vasiliūnaitė 2014; Mačiulis, Tvaronavičienė 2013; Tvaronavičienè et al. 2014; Scaringelli 2014; Vosylius et al. 
2013). In Lithuania, progress of small and medium enterprises (SMEs) is impeded by many environmental factors and conditions. A major one, however, is the public sector which regulates business (Greblikaite, Puškoriūte 2014). Therefore, there is an active search of the measures to improve public sector performance (Bivainis, Tunčikienè 2011; Nakrošis, Černiūte 2010; Nakrošis, Martinaitis 2009; Bučinskas et al. 2013). It is suggested that problems in the area of activity of institutions can be solved with using business practice tested management tools, such as strategic planning, programme based budgeting, marketing, models of quality management, forms of network management, etc. In the context of growing environmental demands and expectations in respect of public sector, it becomes necessary to justify activities of institutions in the light of creating preconditions for implementation of country's development priorities. For this purpose, application of the functions review method in public sector has been internationally recognised as appropriate (Integrity review ...2013; Public Sector Modernisation...2004). In Lithuania, the regulation of the functional review has been in place for several years.

However, recognising the role of functions' review, or even legitimating it, is only one of the preconditions for its implementation. Effective application of this tool requires preparatory work, involving a difficult phase of designing models for functional review and their further development into methods. It is not at all easy due to still unresolved issues relating to the methodological basis (Afonso et al. 2010; Borge et al. 2008; Dudina, Sprindzuks 2006; Functional reviews and ... 2008; Gromov 2007; Lukashenko 2009; Manning, Parison 2004; Maslenikova 2002; Medvedev 2002; Petrov 2002a, b; Reed 2010; Resolution No. 968 ... 2011, 2013; Samarucha 2008). Undoubtedly, reasonable answer to these questions would allow to apply functional review as a tool of effective management, or more precisely, strategic planning in public sector.

The situation where, on the one hand, there is a high need for practice and, one the other hand, there is a lack of methodological approaches, determined the objectives of our research - to identify the place of functions review in strategic planning of institution, to investigate the existing methodological basis of the functions review and preconditions for the supplementation thereof, to draw up recommendations for selecting a methodological approach to the analysis of functions, and to justify the appropriateness of integrated methodology use of functions review. The research employed the systematic analysis method which enabled carrying out a logic abstraction-based synthesis of approaches, assessments and interpretations used by various authors and organisations with regard to the functions review.

\section{The place of functions review in strategic planning of public institution}

An arsenal of measures for improving institutional performance management is permanently supplemented (if not in essence, then at least in form) along with constantly changing conditions in public sector environment. Public organisations are prone to novelties, but their implementation is usually scarce, episodic and lacking radicalism (Raipa, Jurkšiene 2013). For instance, the New Programme for the Improvement of Public Administration 2012 - 2020 (Resolution No. 171 ... 2012) provides for insufficiently radical changes in the administration of public sector, which implementation is based on the established administration practice of ensuring the organisation and supervision of activities mainly through the implementation of the management indicators and, at the same time, of the provisions attributable to the New Public Management (NPM) with specification of the existing administrative regulation (Bileišis 2012).

There is an undeniable need for designing new type organisations of high technological level in the public sector that are capable of quick adaptation (Bučinskas et al. 2012; Raipa, Jurkštienè 2013). For this purpose, both theorists and practitioners recognise strategic planning as a tool for the sustainable development of the activities of institutions (Bivainis, Tunčikienè 2009, 2011; Raipa, Jurkšienė 2013; Resolution No. 827...2012; Skačkauskienè et al. 2013). Today this tool is targeted on broader consumer value orientations, competitive opportunities, possibilities for a complex conception of the improved management of public institutions' activities (Melian-Gonzalez et al. 2010). Taking institutional strategic planning as a flexible performance management tool rather than a normative one (the latter concept of strategic planning was particularly followed in the earlier versions of strategic planning methodology (Resolution No. 480 ... 2011), the current version of the methodology is viewed more positively in this respect (Resolution No. 827..2012)), it is appropriate to look for coherence and complementarity of different instruments for improving the management of institutions' 
activities. Functions review is one of the measures found rational to coherently supplement institutional strategic planning instrumentation (Tunčikienè et al. 2013). In case of such integration, review of functions becomes an evidence-based and result-oriented management tool (Report of the activity of the State... 2012).

The current version of the methodology for strategic planning of public institutions (Resolution No. 827...2012) promotes (although not directly in every sense) application of functions review for dealing with solitary tasks of strategic planning. According to the methodology, the preparation of an action plan project of an appropriations manager starts with an environmental analysis and review of programmes in progress. It is rational to use the results of such analysis in later stages of drafting the strategic actions plan of institutions, i.e. for adjustment of the mission, forecasting strategic changes, setting strategic objectives and preparing programmes for their implementation. In addition, the current Strategic Planning Methodology stipulates that the need to apply mentioned functions review and other NPM tools (e.g. programme evaluation, zero-based budgeting approaches) in order to reach different agreements of interests and influences on planned decisions and their results, as well as on the limits of appropriations, should be considered on the level of the Office of the Prime Minister rather than on institutional level.

In order to increase coherence among individual measures of managing the sustainable development of activities and concurrently justify the appropriateness of supplementing strategic planning instruments with functions review, it is first of all rational to set out in detail the link between strategic planning and functions review. Special literature (Manning, Parison 2004; Recommendations for the application ... 2011) analyses the link between functions review and budgeting processes, and, at the same time, evaluation of budget programmes. Given the rationally composed set of strategic planning objectives (Bivainis, Tunčikienè 2009, 2011; Resolution No. 827 ... 2012; Tunčikienè, Skačkauskienè 2012), the analysis of the link between functions review and evaluation of budget programmes enables establishing the place of functions review and its role in the institutional strategic planning.

A functions review can have either a direct or indirect link with the budget programme evaluation (Recommendations for the application...2011):

- The use of functions review results in making decisions on the allocation of appropriations to institutions can be regarded as a direct link. Subject to the findings of functions review, reduction of management costs can be differentiated in respect of the role of an institution and its particular functions.

- The institution's decision to conduct a functions review resulting from decreasing budget appropriations and thus to look for performance effectiveness enhancement reserves can be regarded as an indirect link. Functions review results for institution provide a basis for appropriations required for future or present programmes of institution.

According to experts from the World Bank (Manning, Parison 2004), results of functions review are linked with the budget cycle and strategic planning process. The diagram of integrating the functions reviews into the cycle of budgeting and, at the same time, strategic planning is presented in Figure 1.

The functions review allows obtaining a full information picture which is necessary for assessing changes (quantitative and qualitative) in institution's activities resulting from the implementation of the strategic actions plan within a defined time period: information on the activities carried out by the institution, information on financial allocations for certain activities, information on the achievement of activity results. In addition, information of such a kind is useful in the context of identification of reserves for further promotion of targeted institutional developments and for making decisions as to the future funding required for the performance of activities geared towards the planned perspective. Moreover, the purpose of the functions review is to create preconditions for justifying the validity of next year appropriations sought by institutions (Dudina, Sprindzuks 2006; Functional reviews and...2008; Gromov 2007; Lukashenko 2009; Maslenikova 2002; Medvedev 2002; Petrov 2002a,b; Reed 2010; Samarucha 2008; The report on investigating...2010). Hence, the functional review enables addressing the fundamental strategic planning tasks of public institutions (to create preconditions for efficient allocation and rational use of budget funds, etc. (Bivainis, Tunčikienè 2009; Butkevičius, Bivainis 2009; Report of the activity of the State...2012) with a view to implementing strategic goals of institutions and priorities of the Government. 


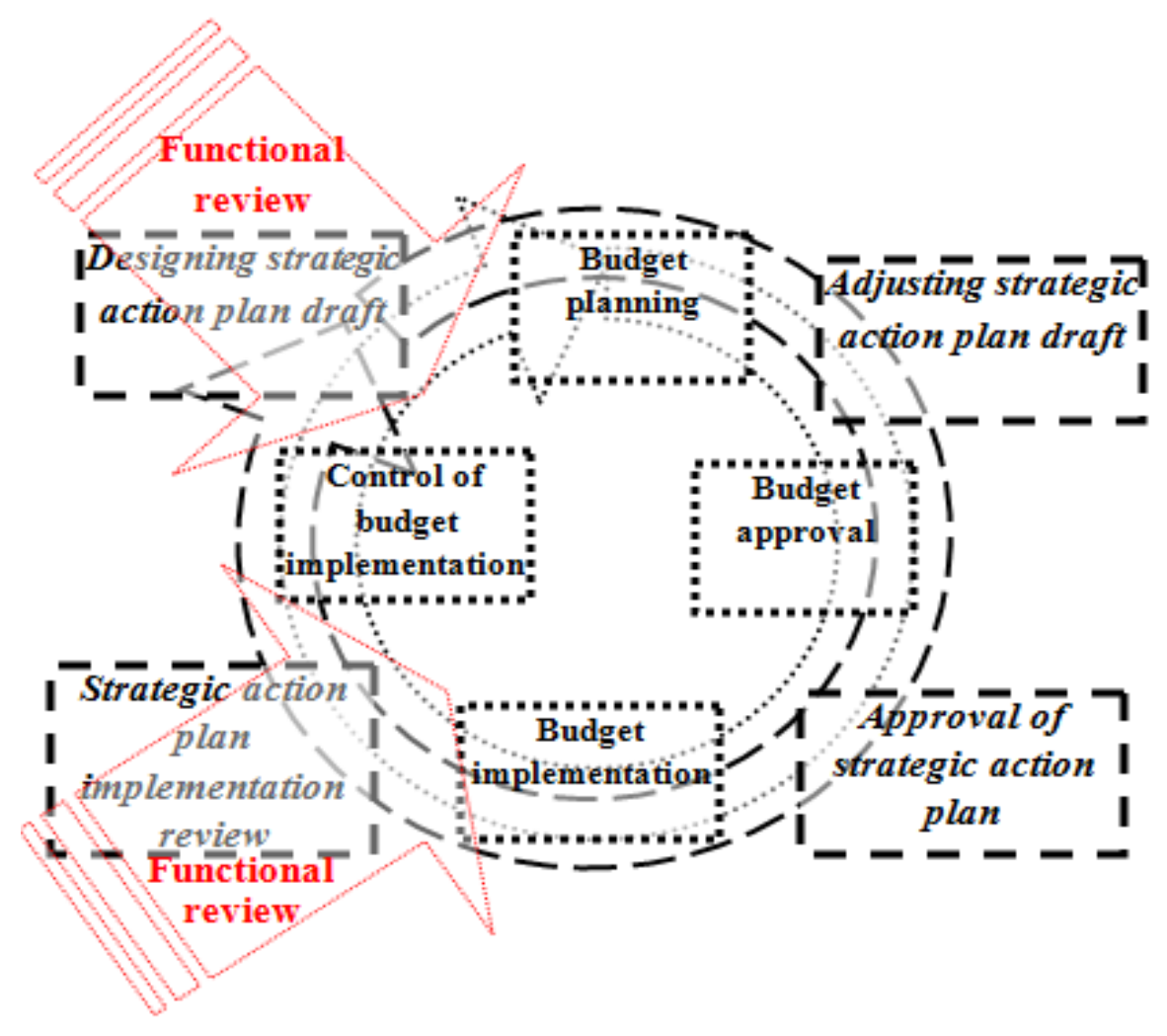

Fig. 1. Integration of functional review into the cycle of budgeting/strategic planning

Source: composed by the authors in accordance with Manning, Parison (2004); Recommendations for the application ... (2011)

The linkage between functions reviews and strategic planning derives from the assumption of the appropriateness of applying management tools in general: both institutional activity management tools in fact contribute to the rationalisation of budget expenditure. The goal of strategic planning in an institution is to create preconditions for increasing the efficiency of future-oriented activities of the institution, whereas the objective of strategic planning encompasses possibilities for coherence of institution's activities with its environment. The functions review is oriented towards creation of conditions for preparing and making the decisions that determine qualitative changes in public sector activities, basing them on the analyses results of the expedience of the institutions' activities as well as rationality and efficiency of their management. The object of functions review is the functions performed by institutions (their units) in the area of implementing national social and economic development priorities and, at the same time, satisfying public needs and expectations in the global market (Drejeris et al. 2013; Tunčikienè et al. 2013). In different phases of the institutional strategic planning cycle it may become necessary to conduct a functions review by analysing the institution's performance potential to implement a programme (whether continued or new) in an efficient manner and to pursue the goals set. According to the purpose is suggested to adapt the methodological potential for evaluating the effectiveness of the activity in public institutions (Afonso et al. 2010; Arend, Levesque 2010; Borge et al. 2008; Lonti, Woods 2007; Modell 2009; Pedraja-Chaparro et al. 2005).

Table 1 shows the peculiarities of integrating the functions review into the institution's strategic planning cycle by specifying the purpose of the functions review and conditions of its application in different phases of the planning cycle. Where specifically appropriate, the functions review may supplement the evaluation of planning decisions in every phase. 
Table 1. Peculiarities of integrating the functions review into the institution's strategic planning cycle

\begin{tabular}{|c|c|c|c|}
\hline $\begin{array}{c}\text { Cycle phases } \\
\text { Tool integration } \\
\text { conditions }\end{array}$ & $\begin{array}{c}\text { Design and adoption of strategic } \\
\text { action plan }\end{array}$ & $\begin{array}{c}\text { Implementation of strategic } \\
\text { action plan }\end{array}$ & $\begin{array}{c}\text { Monitoring of strategic action plan } \\
\text { implementation }\end{array}$ \\
\hline PURPOSE & $\begin{array}{c}\text { Functions review supplements the } \\
\text { ex-ante evaluation of a strategic } \\
\text { background, target orientation, } \\
\text { strategic decisions and their } \\
\text { implementation action programme. }\end{array}$ & $\begin{array}{c}\text { Functions review supplements the } \\
\text { mid-term evaluation of a strategic } \\
\text { action pan (target orientation, } \\
\text { strategic decisions and their } \\
\text { implementation action } \\
\text { programme) }\end{array}$ & $\begin{array}{c}\text { Functions review supplements the } \\
\text { final evaluation of a strategic action } \\
\text { pan (target orientation, strategic } \\
\text { decisions and their implementation } \\
\text { action programme). }\end{array}$ \\
\hline NEED & $\begin{array}{c}\text { There is a need to revise the target } \\
\text { orientation, adopt strategic } \\
\text { decisions on the implementation of } \\
\text { the revised target orientation and } \\
\text { their implementation action } \\
\text { programme in terms of function } \\
\text { content and process. }\end{array}$ & $\begin{array}{c}\text { Monitoring results show } \\
\text { deviations from the set goals and } \\
\text { their implementation targets. } \\
\text { There is a need to analyse the } \\
\text { causes of deviations in terms of } \\
\text { function content and process }\end{array}$ & $\begin{array}{c}\text { Monitoring results raise a } \\
\text { organisation - whether better results } \\
\text { could have been achieved with the } \\
\text { same resources and competences? }\end{array}$ \\
\hline
\end{tabular}

Source: composed by the authors in accordance with Recommendations for the application ... 2011.

\section{Methodological basis of functions reviews}

Methodological preconditions are relevant with a view to coherence of functions review and strategic planning, as well as the synergic effect of application thereof. According to Manning and Parison (2004), etc. (Petrov 2002a, b), the methodological basis of functions reviews consists of procedures performed and methods applied in the process. The principal chart of functions review is presented in Figure 2.

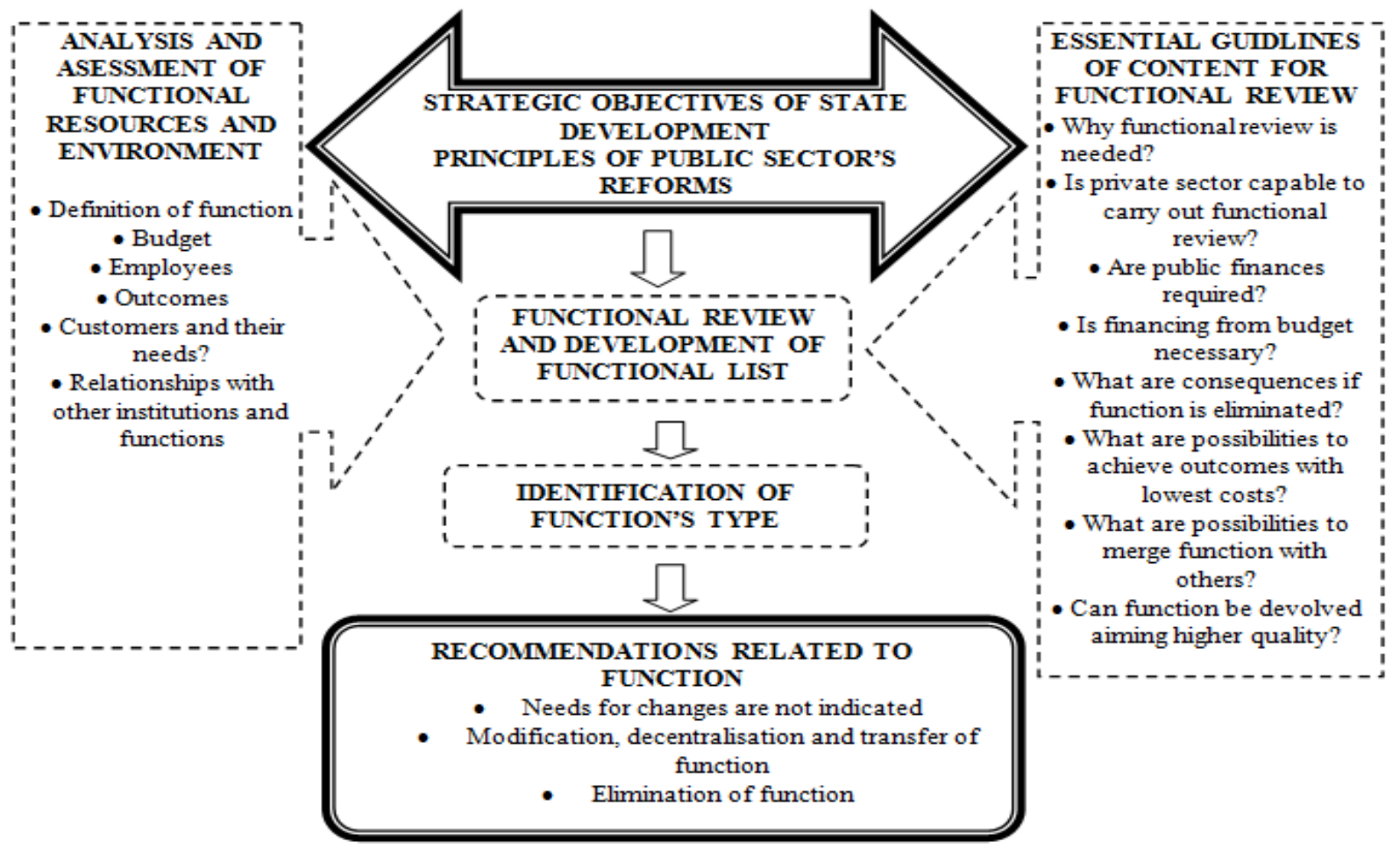

Fig. 2. Methodological basis of functional review

Source: modified by the authors in accordance with Manning, Parison (2004); Recommendations for the application... (2011); Tunčikienè, Korsakienè (2014) 
The principal function review scheme (see Fig. 2) enables the analysis of a function against its background which comprises the results of the analysis and evaluation of function environment and resources, long-term national development goals and basic principles of public reform, as well as basic guidelines for functions review content. The functions review based on searching for answers to the given questions, drawing up of the list of rationally-composed functions, classification of functions by the defined characteristics represent the set of tasks of functions review with recommendations for the function as the ultimate outcome.

\section{Preconditions for supplementing the methodological basis of functions review}

In order to fundamentally incorporate the functions review tool into strategic planning of public institutions and to achieve the synergetic effect that promotes targeted development of institutional performance, it is logical to answer such questions as: whether the methodological basis of functions review is consistent with the strategic planning methodology; what options are possible in methodological approaches to functions review, in the light of traditional strategic planning methodologies; what methodological approaches to functions review are appropriate to be used as a basis for the functions review in institutions? Coherence (undeniable) of functions review and strategic planning methodologies can be based on:

- The link between the goal of functions review and strategic planning and the implementation tasks for achieving the goal. This link provides sufficient basis to consider the functions review an integral part of individual components of strategic planning;

- The principles of functions review and strategic planning. A summary of the principles for functions review and strategic planning found in special literature leads to a distinction to be drawn between two main groups of such principles representing the insights of symptoms of development barriers and opportunities, apprehension and solution of development-related problems, choice of activity development trends and the significance of their implementation (Bivainis, Tunčikienè 2009; Raipa et al. 2011; Tunčikienè et al. 2013).

Given the purpose of functions review in planning longer-term activity of institutions, it is rational to follow a read-across principle by characterising methodological approaches to functions review according to the systematised specifics of strategic planning methodologies in the context of public institutions (Bivanis, Tunčikienė 2009). Following a prescriptive methodological approach, functions review is based on the principles of comprehensive theory of preparing and making decisions which recognises sufficient foresight of the future, systematic complexity, necessary certainty, large formalisation opportunities, and multi-sided adaptation of decisions to a structure and other possibilities, as well as consistency of steps. The emergent approach is helpful in seeking such functions review results that would enable preparation, adoption and implementation of decisions that increase possibilities for greater coherence between institutions and their environmental demands. In case of an emergent methodological approach, preparation of a functions review model is considered as a less strict process of the backdrop of functions review, the functional review itself and drawing up and implementing the recommendations based on its conclusions. This approach also employs formalised rules and procedures, but they are not organised into one, strictly consistent, whole of steps. Such functions review is uninterruptible, with its individual iterations being determined by negotiations and knowledge results. Intent is the dominant aspect in the functional review process, with the key focus being placed on how to develop institutional resources for using the existing potential. The key methodological principles of functions reviews can be specified in more detail following the same logic which is applied to characterise the methodological aspects for implementing the strategic planning principles at the phases of designing a strategic background, setting target orientation, and preparation, adoption and implementation of strategic decisions (Bivainis, Tunčikienè 2009).

Taking into consideration the impact of environmental factors on institution's activities, as well as given the resources and competences of institutions, the formed totality of the specific features of institution's adaptation to the changing environmental conditions and requirements constitutes a common factor determining the choice of methodological approaches to functions review. 


\section{Technique of selecting methodological approaches to functions review in institutions}

It is proposed to analyse the environmental characteristics of public institutions using the created solid methodological potential for environment analysis (Vasiliauskas 2007) or, more specifically, a method of environmental turbulence analysis modified by the authors. The essence of the method is to identify the level of environmental turbulence by the assessment the environment according to the qualitative criteria. The method is applied to assess the following aspects determining the nature of changes in the institutional environment: complexity, novelty, pace and predictability of environmental changes. The outcome of using the method is the estimate (a particular score expressed in points) of the institutional environment level of turbulence - ETL total (for better objectivity it is proposed to use two estimation techniques for setting weights of the main environmental factors) which requires the following interim results (see Table 2 and Table 3):

- Assessment of the components of the institutional environment (political, economic, social and technological environment) separately by each criteria characterising environmental turbulence (complexity $-K_{l}$, novelty $-K_{2}$, pace of changes $-K_{3}$, predictability $-K_{4}$ ) and by the integrated criterion (turbulence $-T L_{i}$ );

- Assessment of the general institutional environment by each criteria characterising environmental turbulence $\left(P E S T V_{i}\right)$;

Table 2. Components of turbulence of the institutional environment and its elements (in formalised expression)

\begin{tabular}{|l|c|c|c|c|c|}
\hline $\begin{array}{r}\text { Criteria } \\
\text { Components of the environment }\end{array}$ & $\begin{array}{c}\text { Complexity } \\
\left(K_{l}\right)\end{array}$ & Novelty $\left(K_{2}\right)$ & $\begin{array}{c}\text { Pace of } \\
\text { changes }\left(K_{3}\right)\end{array}$ & Predictability $\left(\mathrm{K}_{4}\right)$ & $T L_{i}$ \\
\hline Political environment (P) & $P V_{1}$ & $P V_{2}$ & $P V_{3}$ & $P V_{4}$ & $T L_{P}$ \\
\hline Economic environment (E) & $E V_{1}$ & $E V_{2}$ & $E V_{3}$ & $E V_{4}$ & $T L_{E}$ \\
\hline Social environment (S) & $S V_{l}$ & $S V_{2}$ & $S V_{3}$ & $T V_{4}$ & $T V_{4}$ \\
\hline Technological environment (T) & $T V_{1}$ & $T V_{2}$ & $T V_{3}$ & $T L_{T}$ \\
\hline \multicolumn{1}{|r|}{$P E S T V_{i}$} & $P E S T V_{1}$ & $P E S T V_{2}$ & $P E S T V_{3}$ & $P E S T V_{4}$ & $E T L_{\text {total }}$ \\
\hline
\end{tabular}

Source: composed by the authors

- Significance of the components scores (political, economic, social, technological) of the institutional environment $\left(q_{i}\right)$ and normalised significance $\left(Q_{i}\right)$ (see Table 3$)$.

Table 3. Significance of the components of the institutional environment (in formalised expression)

\begin{tabular}{|l|c|c|}
\hline \multicolumn{1}{|c|}{ Significance } & Significance (scored) & $\begin{array}{c}\text { Significance (normalised) } \\
\left(Q_{i}\right)\end{array}$ \\
Components of the environment & $\left(q_{i}\right)$ & $Q_{P}$ \\
\hline Political environment (P) & $q_{p}$ & $Q_{E}$ \\
\hline Economic environment (E) & $q_{e}$ & $Q_{S}$ \\
\hline Social environment (S) & $q_{s}$ & $Q_{T}$ \\
\hline Technological environment (T) & $q_{t}$ & \\
\hline
\end{tabular}

Source: composed by the authors

Experts are offered to analyse the characteristics of the institutional environment using a rationally composed questionnaire with answers variants and particular scores (expressed in points) attached to each answer (see Table 4). If it is difficult to produce unambiguous estimates of environmental characteristics, it is reasonable to use score intervals, i.e., to identify the minimum and maximum ( $\min$ and $\max$ ) values of the factors determining environmental turbulence. 
Table 4. Questionnaire for the scoring of each component of the institutional environment (P-E-S-T)

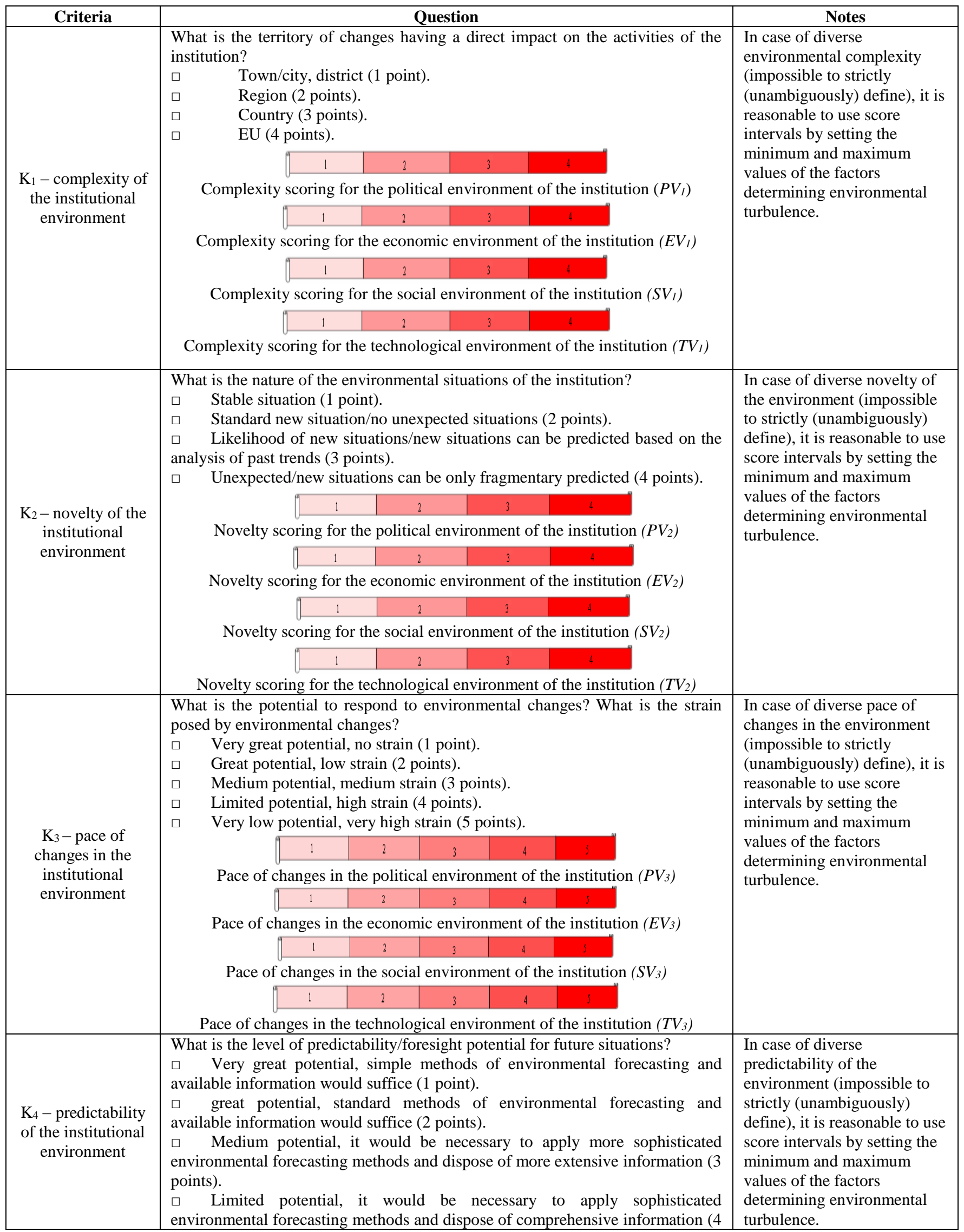




\begin{tabular}{|l|l|}
\hline $\begin{array}{l}\text { points). } \\
\square \\
\text { environmental forecasting methods and dispose of comprehensive information (5 } \\
\text { points). }\end{array}$ \\
Predictability scoring for the political environment of the institution $\left(P V_{4}\right)$ \\
Predictability scoring for the economic environment of the institution $\left(E V_{4}\right)$ \\
Predictability scoring for the social environment of the institution $\left(S V_{4}\right)$ \\
Predictability scoring for the technological environment of the institution $\left(T V_{4}\right)$
\end{tabular}

Source: composed by the authors

Turbulence evaluation $\left(T L_{i}\right)$ for the components of the institutional environment (political, economic, social and technological - P-E-S-T) using the integrated criterion (assessment of turbulence at the level of single environmental component):

$$
\begin{gathered}
T L_{P}=0,25 * P V_{1}+0,25 * P V_{2}+0,25 * P V_{3}+0,25 * P V_{4}, \\
T L_{E}=0,25 * E V_{1}+0,25 * E V_{2}+0,25 * E V_{3}+0,25 * E V_{4} \\
T L_{S}=0,25 * S V_{1}+0,25 * S V_{2}+0,25 * S V_{3}+0,25 * S V_{4}, \\
T L_{T}=0,25 * T V_{1}+0,25 * T V_{2}+0,25 * T V_{3}+0,25 * T V_{4} .
\end{gathered}
$$

Evaluation $\left(P E S T V_{i}\right)$ of each factor (complexity, novelty, pace of changes, predictability) that determines turbulence of the overall institution's environment (PEST):

$$
\begin{aligned}
& \operatorname{PESTV}_{1}=\frac{P V_{1}+E V_{1}+S V_{1}+T V_{1}}{4}, \\
& \operatorname{PESTV}_{2}=\frac{P V_{2}+E V_{2}+S V_{2}+T V_{2}}{4}, \\
& \operatorname{PESTV}_{3}=\frac{P V_{3}+E V_{3}+S V_{3}+T V_{3}}{4}, \\
& \operatorname{PESTV}_{4}=\frac{P V_{4}+E V_{4}+S V_{4}+T V_{4}}{4} .
\end{aligned}
$$

Assessment of the individual characteristics of the overall environment is based on the mean estimate of the environmental components in respect to a specific characteristic.

Evaluation of the turbulence level of the overall institution's environment $\left(E T L_{\text {total }}\right)$ where the weights are equal (technique 1):

$$
\text { ETL }_{\text {total }}=0,25 * P E S T V_{1}+0,25 * \text { PESTV }_{2}+0,25 * \text { PESTV }_{3}+0,25 * \text { PESTV }_{4} .
$$

In the second case, we suggest measuring the significance of the institution's environmental components and estimating turbulence of the overall environment taking into account estimation results for turbulence of individual environmental components and their weights. It is further proposed to calculate the level of 
significance $\left(Q_{i}\right)$ of the institution's environmental component (P-E-S-T) on the basis of the relevance of its influence when addressing the issue of improving country's economic competitiveness, taking into account the influence of each environmental component:

$\square \quad$ Very low influence (1 point).

$\square \quad$ Low influence (2 points).

$\square \quad$ Average influence (3 points).

$\square \quad$ High influence (4 points).

$\square \quad$ Very high influence (5 points).

It is rational to convert significance $q_{i},(i=1, \ldots, 4)$ expressed in points into significance $Q_{i}$ on condition, $\sum Q_{i}=1$, $(i=1, \ldots, 4)$ :

$$
\frac{q_{i}}{\sum q_{i}}=Q_{i},(i=1, \ldots, 4)
$$

Calculation of the overall turbulence level $\left(E T L_{\text {total }}\right)$ of the institutional environment, taking into account the significance of the environmental components $\left(Q_{i}\right)$ :

$$
\begin{gathered}
E T L_{\text {total }}=Q_{P} * T L_{P}+Q_{E} * T L_{E}+Q_{S} * T L_{S}+Q_{T} * T L_{T} \\
\text { or } \\
E T L_{\text {total }}=\sum Q_{i} * T L_{i} ; i=1, \ldots, 4 .
\end{gathered}
$$

The results of the level of turbulence of the institutional environmental provide a basis for selecting a methodological approach which is rational for conducting the functional review (see Fig. 3).

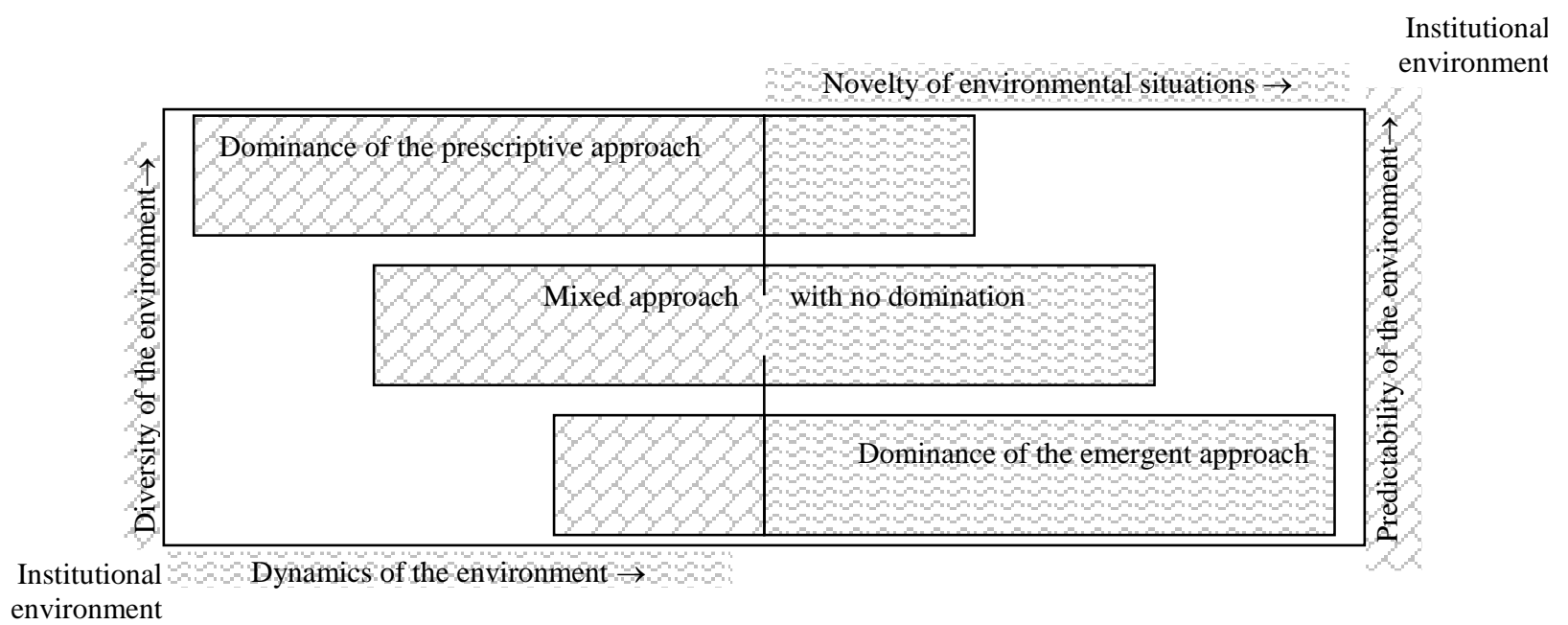

Fig. 3. Matrix of methodological approaches to functional review and their determinants

Source: composed by the authors 


\section{Expedience of applying the integrated methodology to functions review}

Constructing a model of functions review for a public institution based on the principle of an integrated methodological approach means that recommendations for the each function are developed and implemented on the basis of either a prescriptive or emergent methodological approach which is then supplemented with the elements of the other methodology. Elements of different methodological approaches can be combined in different proportions (see Fig. 3). The appropriateness and effectiveness of such methodological principle depends on the following characteristics of the institution's environmental turbulence:

- Diversity of the institutional environment: activities of institutions are influenced by various (political, economic, social, technological, etc.) factors and different groups of interests (users, government, other institutions, etc.). Solutions of the political, economic, social, technological problems and complications based on the results of evaluating the suggestions for the institutional functions, and together satisfaction of the stakeholders' expectations and needs represent an important condition for the necessity of institution's activity and, concurrently, for adapting the institution to environmental changes.

- Diversity and complexity of problems in the institutional environment and complications thereof. Complexity of the political, economic, social and technological environment determines the limits of impact of the proposals for the functions implementation.

- Insufficiently investigated environment of institutions. National institutions apply the principles of the NPV in terms of form rather than content. (Programme budget is every year higher than in the previous year. Next year's appropriations for programme implementation are linked to the expenditure sustained last year and the year before rather than to the achievement of results (Performance Management in Lithuania ... 2007). However, application of modern methods and advanced information technologies allow institutions to predict new situations in the environment. In this context, it is also useful to apply a read-across method - analysis of social-economic development of other countries, comparison of national development and development patterns in foreign countries, adoption of "experience". Certainly, results obtained through application of such methods should be assessed and evaluated with reservations.

- Diversity in the pace of changes in the institutional environment. Institutions may respond to changes in an adequate pace, with delay or even precede the changes. Changes in the institution's environment usually pose strain which is also determined by the status of country's public sector activities in the context of EU countries.

High diversity of the institutional environment is a category which is more allied to the prescriptive methodological approach. Another environmental category - dynamics - is more appropriate for the emergent methodology, with distinction between relevant fragments of the diverse environment, direction of resources to tackling priority problems and complications in the environment. In addition, seeking to promptly adopt and implement solutions to environmental problems and complications in respect of the institution's functions is indicative of the appropriateness of the emergent methodology. Complexity of the institutional environment determines the appropriateness to apply a combination of the prescriptive and emergent methodology. The application of combined approaches in particular creates preconditions for identifying the boundaries of political, legal, economic, social and technological problems of the environment, as well as of the impacts of their solution.

Insufficient level of investigation of the public sector environment is an unfavourable factor for both methodological approaches, and probably can be best dealt with when applying the integrated approach. The prescriptive approach is appropriate for the assessment of possibilities for resource consistency and for using the results of such assessment to justify reserves for promoting the essential changes in institutional activities, whereas the emergent methodology is appropriate for assessing opportunities for the development of institutional resources. The pace of environmental changes which determination is preconditioned by setting strategic objectives and priorities of country's development, understanding of the principles of public reforms and, hence, assessment of problems and complications in the environment, as well as identification of the potential to adequately respond, in terms of the content and process of functions review, to the changing environmental 
conditions and new environmental demands require a combination of the prescriptive and emergent methodological approaches.

The functional review requires updating of the organisational structure of public institutions, development of an advanced leadership style, coherence of institution's philosophy, culture and policy with emerging reforms in the management system. These are human-factor issues that can be better analysed using the emergent methodology approach. It is namely this methodological approach that creates preconditions for ensuring a better coherence of various actors determining the performance of institutions.

\section{Conclusions}

Generally, the following main functions of a state can be distinguished: addressing economic issues, social issues and other functions. The role of the public sector in creating increasingly better conditions for business development in a country has been highlighted. Within the context of the on-going processes (liberalisation of markets, competition that exceeds the boundaries of the farthest countries, social and economic differentiation of the world, change of information technologies, etc.) more active reforms are characteristic of public sector as well as new requirements keep being imposed on the institutions in this sector. Sustainable development and efficiency of public sector remain priority of governments. Hence, governments are concerned with assessment, plan and measure of functions performed by public sector institutions.

While carrying out functions reviews, public institutions face methodological level problems. A major issue is the selection of a methodological approach to functions review. Methodological approaches to the functions review provided in special literature are insufficiently intelligible. Our research allowed to specify the existing methodological basis of the functions review in more detail and to systematise the basic characteristics of methodological approaches to the functions review. Following the prescriptive methodological approach, the functions review is based on the principles of multi-sided decision-making theory. The emergent methodology approach, on the contrary, represents poorer foresight of the future, fragmentary complexity, weaker certainty, more limited formalisation, two-sided adaptation of decisions to a structure, and other possibilities, as well as unstable sequence of steps. These characteristics shall be considered as preconditions for preparing, adopting and implementing decisions that, in the first case, increase possibilities for greater coherence between institutions and their environment demands and, in the second case, are oriented towards development of institutional potential to use the existing potential and prevention of environmental threats.

The article contains recommendations on how to assess the factors determining the selection of methodological approaches to the functional review, identifies the consistent patterns of links between such factors and methodological approaches, and provides recommendations on the application in setting an integrated combination of methodological approaches for a particular situation of public institutions. Implementation of provided suggestions would contribute building more efficient entrepreneurship ecosystem, what would ultimately contribute to sustainable development of country.

\section{References}

Afonso, A.; Schuknecht, L.; Tanzi, V. 2010. Public sector efficiency: evidence for new EU member states and emerging markets, Applied Economic 42 (17): 2147-2164.

Antanavičienè, J. 2014. Foreign direct investment: driving factors and outcomes for secure and sustainable development, Journal of Security and Sustainability Issues 3(3): 55-67. DOI: http://dx.doi.org/10.9770/jssi.2014.3.3(5)

Arend, R. J.; Levesque, M. 2010. Is the resource - based view a practical organizational theory? Organization Science 21 (4): $913-930$.

Bileišis, M. 2012. Empowering institutions: a case for connecting business and the academe through phronesis, Journal of Security and Sustainability Issues 1(3): 177-185.

Bileišis, M. 2014. Public sector control as a factor in entrepreneurial policy: the case of Lithuania, Entrepreneurship and Sustainability Issues 1(3): 151-161. DOI: http://dx.doi.org/10.9770/jesi.2014.1.3(4) 
Bivainis, J.; Tunčikienè, Ž. 2009. Viešojo sektoriaus institucijų strateginis planavimas [Strategic planning in public institutions]. Vilnius: Technika, $240 \mathrm{p}$.

Bivainis, J.; Tunčikienè, Ž. 2011. Viešojo sektoriaus instituciju strateginio valdymo biurokratija [Bureaucracy of strategic management in public institutions] in the collective monograph Biurokratija demokratineje visuomeneje [Bureaucracy in a democratic society]. Ats. red. [editor-in-chief] Raipa, A. Kaunas: Technologija. 280 p.

Borge, L. E.; Falch, T.; Tovmo, P. 2008. Public sector efficiency: the roles of political and budgetary institutions, fiscal capacity and democratic participation, Public Choice 136(3-4): 475-495.

Bučinskas, A.; Giedraityte, V.; Raipa, A. 2013. Networking in the structure of public governance changes, Regional Formation and Development Studies 10(2): 47-56.

Butkevičius, A.; Bivainis, J. 2009. Nacionalinio biudžeto išlaidų planavimas [Planning the National Budget Expenditure]. Vilnius: Technika, $248 \mathrm{p}$.

De Alencar, L.M.; Almeida, H.N. 2013. Economic viability and sustainability of solidarity economy enterprises: a case study on the technological incubator of popular cooperatives of the Catholic University of Salvador, Entrepreneurship and Sustainability Issues 1(2): 92-98. DOI: http://dx.doi.org/10.9770/jesi.2013.1.2(3)

Drejeris, R.; Bivainis, J; Tunčikienè, Ž.; Drejerienè, E. 2013. Determining the purposefulness of new services on the grounds of the results of quantitative analysis, Journal of Business Economics and Management 14(4): 791-805.

Dudina, A.; Sprindzuks, M. 2006. The Functional review of the administration of the parliament of the Republic of Moldova. Available from Internet:

<http://www.undp.md/publications/doc/mission\%20reports/Functional\%20review\%20of\%20the\%20Parliament\%20of\%20the\%20RM.pd f.>.

Functional reviews and institutional audit of six public sector institutions to assess the impact of ongoing public sector reforms. 2008. Final report. Available from Internet: <http://www.mineduc.gov.rw/innovation/IMG/pdf/Functional_20Review_20_20Final_20report_1_.pdf.>.

Garškaitè-Milvydienè, K. 2014. Anti-crisis management of enterprises and possibilities of overcoming their critical condition, Journal of Entrepreneurship and Sustainability Issues 1(4): 187-203. DOI: http://dx.doi.org/10.9770/jesi.2014.1.4(1)

Giriūnienè, G. 2013. Public sector's subsidies to business - suitability valuation of labor market support measures, Entrepreneurship and Sustainability Issues 1(1): 37-44. DOI: http://dx.doi.org/10.9770/jesi.2013.1.1(4)

Greblikaitè, J.; Puškoriūtè, N. 2014. Stimulation and encouragement of Lithuanian small and medium-size enterprises, improving public sector services for business, Public Policy and Administration 13(1): 137-148.

Gromov, J. N. 2007. Increasing the competitive ability of economics, development of human capital and modernizing state government institutions within the region through ICT 2007. Available from Internet: <http://www.gisa.ru/40397.html.>

Integrity review of Italy. Reinforcing public sector integrity, restoring trust for sustainable growth. 2013. OECD. Available from Internet: $<$ http://books.google.lt/books?id=ybPxAAAAQBAJ\&pg=PA54\&lpg=PA54\&dq=function+review+in+public+sector\&source=bl\&ots=yq yCcnSOop\&sig=0QCLpm813ZwRZYH1nZ8FTNOL7TM\&hl=lt\&sa=X\&ei=Y3pwVM3bOaLIyAPi_oL4CA\&ved=0CGwQ6AEwCQ\#v $=$ onepage \&q=function $\% 20$ review\%20in\%20public\%20sector \&f=false $>$

Išoraite, M. 2013. Motivation tools though lenses of prospective employees, Entrepreneurship and Sustainability Issues 1(2):116-123. DOI: http://dx.doi.org/10.9770/jesi.2013.1.2(6)

Korsakienè, R.; Tvaronavičienė, M. 2014. Processes of economic development: case of Lithuanian real estate sector, Entrepreneurship and Sustainability Issues 1(3): 162-172 DOI:. http://dx.doi.org/10.9770/jesi.2014.1.3(5)

Lietuvos Respublikos Vyriausybès 2011 m. balandžio 20 d. nutarimas Nr. 480 Dèl Lietuvos Respublikos Vyriausybès 2002 m. birželio 6 d. nutarimo Nr. 827 Dèl strateginio planavimo metodikos patvirtinimo pakeitimo, Valstybès žinios, 2011 [Resolution No. 480 of April 20, 2011 of the Government of the Republic of Lithuania on modification of the resolution No. 827 of June 6, 2002 of the Government of the Republic of Lithuania on approval of the methodology for strategic planning. Official Gazette, 2011].

Lietuvos Respublikos Vyriausybės 2011 m. rugpjūčio 17 d. nutarimas Nr. 968 dèl Lietuvos Respublikos Vyriausybei atskaitingu institucijų funkcijų peržiūros metodikos patvirtinimo, Valstybès žinios, 2011 [Resolution No. 968 of August 17, 2011 of the Government of the Republic of Lithuania on the approval of the methodology for the functional review of institutions accountable to the government. Official Gazette, 2011].

Lietuvos Respublikos Vyriausybės 2012 m. spalio 10 d. nutarimas Nr. 827 Dèl strateginio planavimo metodikos patvirtinimo, Valstybès žinios, 2012 [Resolution No. 827 of October 10 of the Government of the Republic of Lithuania on approval of the methodology for strategic planning, Official Gazette, 2012].

Lietuvos Respublikos Vyriausybès 2012 m. vasario 7 d. nutarimas Nr. 171 Dèl viešojo valdymo tobulinimo 2012-2020 programos patvirtinimo, Valstybés žinios, 2012 [Resolution No. 171 of February 7, 2012 of the Government of the Republic of Lithuania on the approval of the public management improvement program 2012-2020. Official Gazette, 2012]. 
Lietuvos Respublikos Vyriausybės 2013 m. rugpjūčio 21 d. nutarimas Nr. 968 dèl Lietuvos Respublikos Vyriausybei atskaitingu institucijų funkcijų peržiūros metodikos patvirtinimo, Valstybès žinios, 2013 [Resolution No. 968 of August 21, 2013 of the Government of the Republic of Lithuania on the approval of the methodology for the functional review of institutions accountable to the government, Official Gazette, 2013].

Lonti, Z.; Woods, M. 2007. Measuring productivity and efficiency in the public sector. Towards government at a glance: identification of core data and issues related to public sector efficiency, 16: 15-20. Available from Internet:

<http://search.oecd.org/officialdocuments/?hf=10\&b=0\&sl=official_documents\&q=Lonti\%2C+Z.!V!+Woods\&s=desc(document_lastmo difieddate) $>$

Lukashenko, O. 2009. Towards effective public administration: methodology for functional analysis. UNDP Serbia, 32 p. Available from Internet: 〈http://www.undp.org.rs/index.cfm?event=public.publicationsDetails\&revid=D87C2863-FAC3-51E2-DB6E2B8A5080A777 >

Mačiulis, A.; Tvaronavičienè, M. 2013. Secure and sustainable development: Lithuania's new role in taking the Presidency of the EU, Journal of Security and Sustainability Issues 3(2): 5-13. DOI: http://dx.doi.org/10.9770/jssi.2013.3.2(1)

Manning, N.; Parison, N. 2004. Determining the structure and functions of government: program and functional reviews. World Bank, 91 p. [online], [cited on 30 September]. Available from <http://www1.worldbank.org/publicsector/civilservice/ACSRCourse2007/Session\%208/DeterminingStructureFunctions.pdf.>.

Maslenikova, E. V. 2009. Conducting functional performance review of the state executive authorities on the level of the region. Rostovna-Donnu [online], [cited on 30 September]. Available from Internet:

〈http://www.ar.gov.ru/common/img/uploaded/functional_review.pdf $>$.

Medvedev, A. M. 2002. Methodology of conducting functional performance review of the state executive authorities [online], [cited on

30 September]. Available from Internet:

〈http://ar.economy.gov.ru/ru/about/assistance/donors/projects_programms/metodes/?id4=662\&i4=3 >.

Melian-Gonzalez, A.; Batista-Canino, R. M.; Sanchez-Medina, A. 2010. Identifying and assessing valuable resources and core capabilities in public organizations, International Review of Administrative Sciences 76 (1): 97-114.

Modell, S. 2009. Institutional research on performance measurement and management in the public sector accounting literature: a review and assessment, Financial Accountability \& Management 25(3): 277-303.

Nakrošis, V.; Černiūtè, R. 2010. Quality management in the Lithuanian public administration: main initiatives and their application, Public Policy and Administration 31: 63-76.

Nakrošis, V.; Martinaitis, Ž. 2009. The Lithuanian public sector organizations: the EU-driven expansion within the domestic arrangements of autonomy and control, Public Policy and Administration 29: 18-27.

Pedraja-Chaparro, F.; Salinas-Jimenez, J.; Smith, P. C. 2005. Assessing public sector efficiency: issues and methodologies, Public Expenditure 343-360.

Performance management in Lithuania: do we have an efficient government? 2007. Summary of research [online], [cited on 30 September]. Public Policy and Management Institute. Available from Internet: <http://www.vpvi.lt/assets/Ataskaitos/Rezultatuvyriausybe-santrauka.pdf $>$.

Petrov, V. P. 2002b. Methodology and techniques of functional review. Reform of state management: search for an efficient approach. 2002, 24-44 [online], [cited on 30 September]. Available from Internet: <http://gov.cap.ru/home/25/fr glava\%203 rus.pdf.>.

Petrov. V. P. 2002a.Organizing functional review. Reform of state management: search for an efficient approach, 9-15. [online], [cited on 30 September]. Available from: <http://gov.cap.ru/home/25/fr_glava\%202_rus.pdf.>.

Prause, G.; Hunke, K. 2014. Sustainable entrepreneurship along green corridor, Entrepreneurship and Sustainability Issues 1(3): 124133. DOI: http://dx.doi.org/10.9770/jesi.2014.1.3(1)

Caurkubule, Ž.; Rubanovskis, A. 2014. Pension system development and the sustainability of the principle of generation solidarity, Entrepreneurship and Sustainability Issues 1(3): 173-186. DOI: http://dx.doi.org/10.9770/jesi.2014.1.3(6)

Public sector modernisation: Governing for performance. October 2004. OECD. Available from:

<http://www.oecd.org/site/govgfg/39044817.pdf>.

Raipa, A.; Jurkšienè, L. 2013. Innovativeness by modernizing public governance: comparative analysis of Baltic States and Denmark, Economics and Management: Current Issues and Perspectives 3(31): 22-32.

Raudeliūnienė, J.; Tvaronavičienè, M.; Dzemyda, I. 2014. Towards economic security and sustainability: key success factors of sustainable entrepreneurship in conditions of global economy, Journal of Security and Sustainability Issues 3(4): 71-79. DOI: http://dx.doi.org/10.9770/jssi.2014.3.4(7)

Recommendations for the application of the methodology for the functional review of institutions accountable to the government. 2011 [online], [cited on 30 September]. Available from Internet:

<http://www.lrv.lt/bylos/VORT/Documents/Recommendations\%20for\%20the \%20application\%20of\%20the\%20methodology\%20for\%20 the\%20functional\%20review\%20.pdf>. 
Reed, P. J. 2010. Functional and management reviews in the context of economic downturn. UNDP RCPAR Workshop on functional reviews and audits in Kiev, Ukraine, 12 p.

Report of the activity of state governance improvement commission (Sunset Commission) in 2009-2012. Results and guidelines for further changes. 2012 [online], [cited on 30 September]. Available from: <http://www.lrv.lt/bylos/veikla/veiklosataskaitos/Saulelydzio\%20ataskaita_2012\%2011\%2014.pdf>

Samarucha, A. V. 2008. The problem of redundant and overlapping functions of the executive bodies of state power in the region [online], [cited on September 30]. Available from: 〈http://www.usue.ru/files/structure/Izd/Izvestiya-UrGEU_2\%2821\%29_2008.pdf>

Samoška, M. 2011. The analysis of ease of doing business assessment methods, Science - Future of Lithuania 3(4): 82-89.

Samoška, M. 2013. Prosperity, human evelopment and ease of doing business research analysis, Science - Future of Lithuania 5(1): 1-6.

Scaringelli, M.A. 2014.Are the foreign controlled firms more environmentally sustainable than domestically controlled ones?, Journal of Security and Sustainability Issues 4(2): 131-146. DOI: http://dx.doi.org/10.9770/jssi.2014.4.2(3)

Skačkauskienè, I.; Okunevičiūtè Neverauskienė, L.; Zabarauskaite, R.; Andriušaitienė, D.; Tunčikienė, Ž. 2013. Socio-economic issues and assumptions for decision making in Lithuania. Vilnius: Technika, 168 p.

Šabasevičienė, V.; Grybaite, V. 2014. Main foreign direct investment factors as precondition of sustainable entrepreneurship: evidence from Lithuania, Central and Eastern Europe, Entrepreneurship and Sustainability Issues 1(4): 230-238. DOI: http://dx.doi.org/10.9770/jesi.2014.1.4(5)

Šimelytė, A.; Antanavičienè, J. 2013. Economic development and its influence on state capital structure, Entrepreneurship and Sustainability Issues (1): 1-9. DOI: http://dx.doi.org/10.9770/jesi.2013.1(1)

The report on investigating the tools of functional review and evaluation of budget programs in Lithuania and foreign countries. 2010 [online], [cited on September 30]. Available from: 〈http://www.lrv.lt/bylos/VORTprojektas/Dokumentai/knyga2.pdf. . .

Tunčikienè, Ž.; Korsakienè, R. 2014. Sustainable development of public institutions: The model of functional review, Journal of Security and Sustainability Issues 4(2): 187-195. DOI: http://dx.doi.org/10.9770/jssi.2014.4.2(7)

Tunčikienè, Ž.; Skačkauskienė, I. 2012. The state of public sector institution strategic planning and preconditions for its improvement, Social Sciences Studies 4(1): 97-110.

Tunčikienè, Ž.; Skačkauskienè, I.; Grenčikova, A. 2013. Sustainable Development of Public Sector: The State and Assumptions of Improvement of Functional Review in Public Institutions, Journal of Security and Sustainability Issues 3(1): 11-21. DOI: http://dx.doi.org/10.9770/jssi.2013.3.1(2)

Tvaronavičienè, M. 2014. If industrial sector development is sustainable: Lithuania compared to the EU, Entrepreneurship and Sustainability Issues 1(3):134-142. DOI: http://dx.doi.org/10.9770/jesi.2014.1.3(2)

Tvaronavičienė, M.; Šimelytė, A., Lace, N. 2014. Sustainable development facets: exporting industrial sectors from inside, Journal of Security and Sustainability Issues 3(4): 37-44. DOI: http://dx.doi.org/10.9770/jssi.2014.3.4(4)

Vasiliauskas, A. 2007. Strateginis valdymas [Strategic Management]. Kaunas: Technologija, 384 p.

Vasiliūnaite, R. 2014. Sustainable development: methodological approaches toward issues, Journal of Security and Sustainability Issues 3(3): 69-75. DOI: http://dx.doi.org/10.9770/jssi.2014.3.3(6)

Vosylius, E.; Rakutis, V.; Tvaronavičienè, M. 2013. Economic growth, sustainable development and energy security nterrelation, Journal of Security and Sustainability Issues 2(3): 5-14. DOI: http://dx.doi.org/10.9770/jssi.2013.2.3(1)

Wahl, M.; Prause, G. 2013. Toward understanding resources, competencies, and capabilities: business model generation approach, Entrepreneurship and Sustainability Issues 1(2): 67-80. DOI: http://dx.doi.org/10.9770/jesi.2013.1.2(1)

Živilė TUNČIKIENĖ. Associate Professor. Department of Social Economics and Business Management, Faculty of Business Management, Vilnius Gediminas Technical University. Research interests: management of socioeconomic development, strategic management of public sector.

Rolandas DREJERIS. Doctor, Associate Professor of Dept of Social Economics and Management, Vilnius Gediminas Technical University. Research interest: innovation management, business strategy, process of services development, quantitative research of business environment.

This is an open access journal and all published articles are licensed under a

Creative Commons Attribution 4.0 International License 